\title{
EFFECT OF PRE-SOWING SEED TREATMENT IN PHYTO-MELIORATION OF SALT-AFFECTED SOILS
}

\author{
Magdy M. Niazy ${ }^{{ }^{*}}$ and M.A. Abd El-Satar ${ }^{2}$ \\ 1. Soils, Water and Environ. Res. Inst., ARC, Giza, Egypt \\ 2. Oil Crops Res. Dept., Field Crops Res. Inst., ARC, Egypt
}

\section{Received: 19/02/2017 ; Accepted: 04/05/2017}

\begin{abstract}
A field experiment was carried out at Tag Al EZZ Agricultural Research Station, ARC, Egypt $\left(31^{\circ} 36^{\prime} \mathrm{N} / 30^{\circ} 57^{\prime} \mathrm{E}\right)$ in two seasons of 2014-2015. This work aimed at assessing the effect of cultivating seeds treated with aerated solution of Salicylic Acid (SA) 1.00, 1.50, 2.00, 2.50 and 3.00 $\mathrm{mM}$ of 3 plants: kenaf (Hibiscus canabienus), sunflower (Helianthus annuus) and canola (Brassica napus) in phyto-remediating (bioreclamination) of a saline soil. Growth of plants (its seeds were presowing treated with salicylic acid) was higher than that of plants its seeds were not treated with the acid. The treatment induced tolerance to salt stress leading to promoting protective reactions to the photosynthetic pigments, maintained the membranes integrity and osmotic adjustment This increased growth led to removal of greater amounts of salts from the soil. Salinity as well as sodicity of the soil where treated plants were grown was lower than in soils where non-treated plants were grown. The $3.00 \mathrm{mM}$ treatment was the most effective.
\end{abstract}

Key words: Pre-sowing, kenaf, sunflower, canola, salicylic acid and phyto-remediating.

\section{INTRODUCTION}

Egypt is one of the highest population densities in the world with an average of 1700 inhabitants per $\mathrm{km}^{2}$ and is one of the countries that suffer severe salinity problems and about $33 \%$ of its cultivated land, is saline (Ghassemi et al., 1995). The salinization is mainly due to low precipitation $(<25 \mathrm{~mm}$ annual rainfall), high temperature (during summer, temperature reaching from 35 to $45^{\circ} \mathrm{C}$ ), high surface evaporation (1500-2400 $\mathrm{mm} /$ year), poor drainage causing rising water table (less than one meter below the soil surface (Amer et al., 1989). Such salinity may reduce production of soils by about 30\% (El-Lakany et al., 1986). Good-quality water are falling short of demand for intensive irrigated agriculture in many arid and semi-arid countries, thus available freshwater supplies need to be used more efficiently. (Minhas, 1996 ; Bouwer, 2002).
The environmentally safe and clean technique of phytoremediation has been introduced to address the salinity problem involving growing salt tolerant plants to remove excess salts from saline soils (Oster et al., 1999). Qadir and Oster (2004) conducted 14 experiments to compare remediation of salt-affected soils by chemicals and through vegetation and found that soil amendment with gypsum reduced $62 \%$ of sodicity and phytoremediation reduced it by $52 \%$. Ghassemi et al. (1995) reported that the vegetative bioremediation of saline-sodic soils was effective in dissolution of calcite through the processes at the soil-root interface resulting in enhanced levels of $\mathrm{Ca}^{2+}$ in soil solution. They concluded that the "vegetative bioremediation $\left(\mathrm{V}_{\mathrm{BIO}}\right)$ " is a function of a number of factors according to the following equation:

$$
V_{\mathrm{Bio}}=\sum R_{\mathrm{PCO} 2}+R_{\mathrm{H}^{+}}+R_{\mathrm{Phy}}+S_{\mathrm{Na}^{+}}
$$

\footnotetext{
*Corresponding author: Tel. : +201093458689

E-mail address: amagdy16@gmail.com
} 
Where $R_{\mathrm{PCO} 2}$ is the increased partial pressure of $\mathrm{CO}_{2}$ within the root zone, $R_{\mathrm{H}^{+}}$is enhanced proton $(\mathrm{H}+)$ release in the root zone in case of certain $\mathrm{N}_{2}$-fixing crops. The $R_{\text {Phy }}$ concerns the physical effect of roots in soil aggregation and hydraulic properties of the root zone. The $S_{\mathrm{Na}^{+}}$is the content $\mathrm{Na}$ in shoots. The collective effects of these factors ultimately lead to soil amelioration.

For effective remediation, plant species used for the phytoremediation process must produce sufficient biomass. Kenaf (Hibiscus cannabinus L.) grow quickly, rising to a height of 1.5 to 3.5 $\mathrm{m}$ and a stem of 1 to $3 \mathrm{~cm}$ diameter within 3 to 4 months (IART, 1997). It can be grown on saline soils (Curtis and Lauchli, 1985) and remove significant amounts of salts from the soil (Francois et al., 1992). Sunflower (Helienthus annuus) is another salt tolerant plant used in removing salts from soil (Ashraf and Tnfail, 1995). Rice (Oryza sitiva) and sunflower proved effective in removing salts from soil (Iwasaki, 1987). Canola (Brassica napus L.) which is an important oil crop that ranks behind soybean and palm oil is another plant used in removing salts from soil (Francois et al., 1984). Canola is an oil crop which can be grown in less fertile salt affected soils relatively economic yield (ElHoweity and Asfour, 2012). Kandil et al. (2012) found that germination percentage, germination index, seedling vigor index, seedling growth and distance between the root hairs and root tips decreased under effect of salinity.

Salicylic acid (SA) plays an important role in abiotic stress tolerance (Haigh et al., 1986; Gray, 1989; Mauromical and Cavallaro, 1995; Asadi et al., 2013) due to its ability to induce a protective effect on plants under stress (Hussain et al., 2010). It produces phenolic compounds which enable plants to endure environmental stresses (Senaratna et al., 2000). Among different methods to cope with salinity, seed priming (pre-sowing seed treatment) is a low cost and low risk method (Muhammad and Muhammad, 2006). Soaking seeds in SA solution provided protection against and salinity stress in wheat (Hamada and Al-Hakimi, 2001). Tari et al. (2002 and 2004) using this method in tomatoes and obtained protection against salinity which they attributed to increased activation of aldose reductase and APx enzymes and accumulation of osmolytes (such as sugars, or proline). The exogenous application of SA was reported to have an effect on a wide range of physiological processes including increased cold germination tolerance in pepper (Korkmaz, 2005), chilling tolerance in cucumber (Kang and Saltveit, 2002) and maize (Janda et al., 2000), salinity tolerance in barley (El-Tayeb, 2005), drought tolerance in tomato and beans (Senaratna et al., 2000) and wheat (Sakhabutdinova et al., 2003). SA plays an important role in adapting redox balance across the membranes thereby counteracting the negative effects of reactive oxygen intermediates caused by oxidative stress (Yang et al., 2004) by increasing the activating of antioxidant enzymes such as superoxide dismutase (Singh and Usha, 2003). It is involved in realization of different anti-stress programs in plants under osmotic stress by increasing the accumulation of lectins in wheat (Shakirova et al., 2003) and fast activation of $48-\mathrm{KD}$ protein kinase in tobacco (Mikolajczyk et al., 2000). The current study, assesses phytoremediation efficiency by treat seeds of some plant species with salicylic acid.

\section{MATERIALS AND METHODS}

Field experiments were conducted at Tag AlEZZ Agricultural Research Station, ARC, Egypt $\left(31^{\circ} 36^{\prime} \mathrm{N} / 30^{\circ} 57^{\prime} \mathrm{E}\right)$, during seasons of 2014-2015 to evaluate the seed treatment with salicylic acid in phytoremidiating saline soils. The plants used for this study were kenaf (Hibiscus canabinus, G3), sunflower (Helianthus annuus, Euroflor) and canola (Brassica napus) cv. Serw 4. Seeds were sterilized with sodium hypochlorite solution $(5 \%)$ for five minutes to eliminate possible seed-borne micro-organisms, then rinsed for 1 minute under running water prior to drying for $30 \mathrm{~min}$ at room temperature. Then, seeds were soaked in an aerated (by an air pump) solution of salicylic acid (SA). Soaking solutions were as follows 0 (Control), 1.00, $1.50,2.00,2.50,3.00 \mathrm{mM}$ for $6 \mathrm{hr}$. Treatment designations being $\mathrm{S}_{0}, \mathrm{~S}_{1}, \mathrm{~S}_{2}, \mathrm{~S}_{3}, \mathrm{~S}_{4}$ and $\mathrm{S}_{5}$, respectively

After pre-soaking, seeds were surface dried on a filter paper for $12 \mathrm{hr}$., at room temperature. These primed seeds as well as the untreated seeds (un-primed seeds) were seeded in a randomized complete block design experiment 
Table 1. Chemical properties of the soil

\begin{tabular}{|c|c|c|c|c|c|c|c|c|c|c|c|c|c|}
\hline \multirow{2}{*}{ 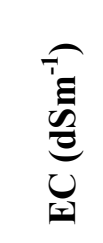 } & \multirow{2}{*}{ 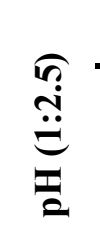 } & \multicolumn{4}{|c|}{ Cations (mmolc $\left.\mathrm{l}^{-1}\right)$} & \multicolumn{4}{|c|}{ Anions (mmolc $\left.\mathrm{l}^{-1}\right)$} & \multirow{2}{*}{$\overrightarrow{\tilde{n}}$} & \multirow{2}{*}{$\underset{\mathscr{C}}{\mathscr{4}}$} & \multirow{2}{*}{ 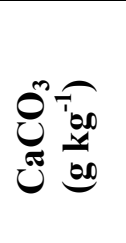 } & \multirow{2}{*}{$\sum_{0}^{\sum_{00}^{00}}$} \\
\hline & & שَّ & $\stackrel{+}{+\infty 0}^{+}$ & $\stackrel{+}{\pi}^{\pi}$ & 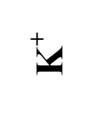 & $\overline{0}$ & $\underbrace{\infty}$ & $\tilde{e}^{1}$ & $\stackrel{\dot{1}}{+}$ & & & & \\
\hline 14.14 & 8.40 & 15.70 & 34.40 & 90.20 & 1.10 & 93.00 & 6.20 & 0.00 & 42.20 & 17.91 & 12.7 & 41.0 & 23 \\
\hline
\end{tabular}

$\mathrm{EC}=$ Electric Conductivity of soil paste extract.

Table 2. Physical properties of the soil

\begin{tabular}{|c|c|c|c|c|c|}
\hline \multicolumn{3}{|c|}{ Particle size distribution (\%) } & \multirow[t]{2}{*}{ Texture } & \multirow{2}{*}{$\begin{array}{l}F^{*} \\
(\%)\end{array}$} & \multirow{2}{*}{$\begin{array}{c}\text { CEC** } \\
\text { Cmolc kg }\end{array}$} \\
\hline Sand & Silt & Clay & & & \\
\hline 7.4 & 36.9 & 55.5 & Clay & 46 & 39 \\
\hline
\end{tabular}

* Field capacity. $\quad * *$ Cation exchange capacity.

Table 3. Chemical analyses of the irrigation water

\begin{tabular}{|c|c|c|c|c|c|c|c|c|c|c|c|}
\hline \multirow[t]{2}{*}{ pH } & \multirow{2}{*}{$\begin{array}{c}E C \\
\left(\mathrm{dS} \mathrm{m^{-1 }}\right)\end{array}$} & \multicolumn{4}{|c|}{ Soluble cations $\left(\mathrm{mmolc}^{-1}\right)$} & \multicolumn{4}{|c|}{ Soluble anions $\left(\mathrm{mmolc}^{-1}\right)$} & \multirow[t]{2}{*}{ SAR } & \multirow{2}{*}{$\begin{array}{l}\text { Water } \\
\text { class* }\end{array}$} \\
\hline & & $\mathrm{Na}^{+}$ & $\mathbf{K}^{+}$ & $\mathrm{Ca}^{2+}$ & $\mathrm{Mg}^{2+}$ & $\mathrm{CO}_{3}{ }^{2-}$ & $\mathrm{HCO}_{3}{ }^{--}$ & $\mathrm{Cl}^{-}$ & $\mathrm{SO}_{4}{ }^{2-}$ & & \\
\hline$\overline{7.3}$ & 1.3 & 8.0 & 0.3 & 3.3 & 1.4 & 0.0 & 4.2 & 4.0 & 4.8 & 5.22 & $\mathrm{C}_{3} \mathrm{~S}_{1}$ \\
\hline
\end{tabular}

*Class of water according to the US salinity Lab. "High salinity low sodicity"

with three replicated. Recommended $\mathrm{P}$ and $\mathrm{K}$ fertilizer were added in rates of $17 \mathrm{~kg} \mathrm{P} \mathrm{ha}^{-1}, 100$ $\mathrm{kg} \mathrm{K}$ ha-1 and $110 \mathrm{~kg} \mathrm{~N}^{-1}$ using Casuperphosphate $\left(70 \mathrm{~g} \mathrm{Pkg}^{-1}\right)$, potassium sulphate $\left(400 \mathrm{~g} \mathrm{~K} \mathrm{~kg}^{-1}\right)$ and ammonium sulphate $(200 \mathrm{gN}$ $\left.\mathrm{kg}^{-1}\right)$ respectively.

At end of growth (150 days for kenaf, 120 days for sunflower and canola) samples of roots and shoots were collected, washed, dried at $70^{\circ} \mathrm{C}$ weighed, and taken for analysis (Richard, 1954). Soil analyses were done according to methods cited by Black et al. (1965) while plants were analyzed using methods cited by Chapman and Pratt (1961).

\section{RESULTS AND DISCUSSION}

\section{Dry Weight of Plant}

Results in Table 4 show the effect of seed treated with salicylic on dry weight of the three tested crops of kenaf, (Hibiscus canabienus), sunflower (Helianthus annuus) and canola (Brassica napus). Treating the seeds with SA caused increases in the weight of plants. Kenaf showed the highest increase in dry weight of shoots $(83.9 \%$ in shoot weight) followed by sunflower $(64.1 \%)$ then canola $(65.6 \%)$. Dry weight of the shoot of plants derived from seeds which were not treated with salicylic acid showed values of $15.2,13.80$ and $7.85 \mathrm{~g} \mathrm{plant}^{-1}$ for Kenaf, sunflower and canola, respectively. Treatments receiving SA increased reaching highest values at the highest concentration of the treatment solutions. Highest values of shoot weight were 27.96, 22.64 and 13.77 for Kenaf, sunflower and canola, respectively. The same pattern of response occurred with weights of roots. The relative increase between the nontreated and highest treatment of dry weight 85.2, 74.6 and 82.6 for roots of Kenaf, sunflower and canola, respectively. 
Table 4. Effect of treated seeds with salicylic acid (SA) on dry weight per plant

\begin{tabular}{|c|c|c|c|c|c|c|c|c|c|c|c|c|}
\hline \multirow{3}{*}{$\begin{array}{l}\text { Pre-Sowing } \\
\text { treatment }\end{array}$} & \multicolumn{4}{|c|}{ Kenaf } & \multicolumn{4}{|c|}{ Sunflower } & \multicolumn{4}{|c|}{ Canola } \\
\hline & \multicolumn{2}{|c|}{ Shoots } & \multicolumn{2}{|c|}{ Roots } & \multicolumn{2}{|c|}{ Shoots } & \multicolumn{2}{|c|}{ Roots } & \multicolumn{2}{|c|}{ Shoot } & \multicolumn{2}{|c|}{ Roots } \\
\hline & $\begin{array}{c}(\mathrm{g} \\
\left.\text { plant }^{-1}\right)\end{array}$ & $\begin{array}{c}\mathrm{RI} \\
(\%)\end{array}$ & $\begin{array}{c}(\mathrm{g} \\
\left.\text { plant }^{-1}\right)\end{array}$ & $\begin{array}{l}* \mathrm{RI} \\
(\%)\end{array}$ & $\begin{array}{c}(\mathrm{g} \\
\left.\text { plant }^{-1}\right)\end{array}$ & $\begin{array}{c}\text { *RI } \\
(\%)\end{array}$ & $\begin{array}{c}(\mathrm{g} \\
\left.\text { plant }^{-1}\right)\end{array}$ & $\begin{array}{c}\text { RI } \\
(\%)\end{array}$ & $\begin{array}{c}(\mathrm{g} \\
\left.\text { plant }^{-1}\right)\end{array}$ & $\begin{array}{l}{ }^{*} \mathrm{RI} \\
(\%)\end{array}$ & $\begin{array}{c}(\mathrm{g} \\
\left.\text { plant }^{-1}\right)\end{array}$ & $\begin{array}{l}\text { *RI } \\
(\%)\end{array}$ \\
\hline$\overline{S_{0}}$ & 15.20 & & 2.70 & & 13.80 & & 1.89 & & 7.85 & & 1.15 & \\
\hline $\mathbf{S}_{1}$ & 17.54 & 15.45 & 2.99 & 11.85 & 16.27 & 17.89 & 1.95 & 3.17 & 10.96 & 39.61 & 1.70 & 47.82 \\
\hline $\mathbf{S}_{2}$ & 19.13 & 25.85 & 3.15 & 16.66 & 17.89 & 29.63 & 2.24 & 18.51 & 12.90 & 64.33 & 1.88 & 63.47 \\
\hline $\mathbf{S}_{\mathbf{3}}$ & 22.43 & 47.56 & 3.35 & 24.07 & 19.04 & 43.06 & 2.64 & 39.68 & 13.01 & 65.73 & 1.95 & 69.56 \\
\hline $\mathbf{S}_{4}$ & 24.28 & 59.73 & 4.10 & 51.85 & 20.28 & 46.59 & 2.79 & 47.61 & 13.50 & 71.97 & 2.00 & 73.91 \\
\hline $\mathbf{S}_{5}$ & 27.96 & 83.94 & 5.00 & 85.18 & 22.64 & 64.04 & 3.30 & 74.60 & 13.77 & 75.41 & 2.10 & 82.60 \\
\hline LSD at $5 \%$ & 1.50 & & 0.94 & & 1.14 & & 0.197 & & 1.38 & & 0.22 & \\
\hline
\end{tabular}

*RI" Relative Increase $(\%)^{\prime \prime}=$ [(weight of SA-treated - weight of non-treated $) \div$ weight of non-treated $\left.)\right] \times 100$

\section{Changes in Soil Chemical Properties Post Harvesting}

Results in Table 5 show that the phytoremediation caused a high and more uniform decrease in soil salinity. Electrical conductivity (EC) in the soil cultivated decreased with SA treatment. The values decreased from being 12.85 to become $8.75 \mathrm{dS}$ $\mathrm{m}^{-1}$ for soils under Kenaf and from 13.00 to 9.90 $\mathrm{dS} \mathrm{m} \mathrm{m}^{-1}$ for soils under sunflower and 13.15 to $10.90 \mathrm{dS} \mathrm{m}^{-1}$ for soils under canola.

Values of $\mathrm{pH}$ in soil cultivated with treated plants decreased. Values were 8.25 decreased to become 8.00 for soils under Kenaf, 8.30 to 8.051 for soils under sunflower and 8.30 to 8.07 for soils under canola.

Exchangeable sodium percentage (ESP) showed a trend similar to that of salinity. Values in the soil cultivated with Kenaf decrease from 16.00 down to 11.90. Those for sunflower ranged from 16.45 down to 12.43 and those for canola ranged from 16.85 down to 13.80 .

The growth of plants increased by treatment with SA. El-Tayeb (2005) found that SA induced a pre-adaptive response to salt stress in barley leading to the promotion of protective reactions to the photosynthetic pigments and maintenance of membrane integrity. Hanan (2007) found that treating wheat and barley plants with SA enhanced antioxidant activities and increased proline levels up to $185 \%$ in the seedlings subjected to saline stress. The current results agree with the findings of (Asadi et al., 2013) who soaked barley seeds in $3 \mathrm{mM}$ SA solution prior to seeding and obtained increases in contents of water, phosphthtic pigments, insoluble saccharine and phosphorus and peroxides in barley seedlings grown under salinity stress. Decreases in soil salinity under plants treated with SA was attributed to increased aggregation of soil under the effect of roots (Bewley, 1997; Tisdall and Oades, 1979). Increased capacity of osmotic adjustment via hormonal priming of plant seeds were obtained by Cayuela et al. (1996) and Ahmed et al. (1998). Francois et al. (1992) reported that the salt removal by kenaf in stems and leaves of untreated plants ranged from 730 to $1233 \mathrm{~kg}$ $\mathrm{ha}^{-1}$.

A decrease in $\mathrm{pH}$ of the soil cultivated with the three plants derived from hormonal priming could be due to $\mathrm{Na}^{+}$removal by plants . Results obtained by Robbins (1986), Ilyas et al. (1997) and Qadir and Oster (2002) showed that $\mathrm{pH}$ decreased with a decrease in $\mathrm{Na}$ in soil. Plant roots could also help transport salts (Elkins, 1985). Decreased sodicity in soil cultivated with the plants treated by hormonal priming was recorded by Qadir et al. (1996) and 
Table 5. Effect of phytoremediation through treating seed with salicylic acid on soil chemical properties post harvesting*

\begin{tabular}{|c|c|c|c|c|c|c|c|c|c|c|c|}
\hline \multirow{2}{*}{$\begin{array}{c}\text { Seed }{ }^{*} \\
\text { treatment }\end{array}$} & \multirow{2}{*}{$\begin{array}{c}E C^{* *} \\
\left(d S ~ m^{-1}\right)\end{array}$} & \multirow[t]{2}{*}{ pH } & \multicolumn{4}{|c|}{ Soluble cations $\left(\mathrm{mmolc}^{-1}\right)$} & \multicolumn{4}{|c|}{ Soluble anions $\left(\right.$ mmolc $\left.^{-1}\right)$} & \multirow[t]{2}{*}{ ESP } \\
\hline & & & $\mathbf{C a}^{++}$ & $\mathbf{M g}^{++}$ & $\mathrm{Na}^{+}$ & $\overline{\mathbf{K}^{+}}$ & $\mathrm{CO}_{3}^{-2}$ & $\mathrm{HCO}_{3}^{-}$ & $\mathrm{Cl}^{-}$ & $\mathrm{SO}_{4}^{-2}$ & \\
\hline \multicolumn{12}{|c|}{ Kenaf } \\
\hline $\mathbf{S}_{\mathbf{0}}$ & 12.85 & 8.25 & 17.60 & 31.42 & 78.38 & 1.10 & - & 5.30 & 81.20 & 42.00 & 16.00 \\
\hline $\mathbf{S}_{1}$ & 11.44 & 8.20 & 19.20 & 30.15 & 63.95 & 1.10 & - & 5.00 & 68.10 & 41.30 & 15.65 \\
\hline $\mathbf{S}_{2}$ & 10.50 & 8.18 & 22.30 & 27.96 & 53.74 & 1.00 & - & 4.29 & 60.42 & 40.29 & 15.25 \\
\hline $\mathbf{S}_{\mathbf{3}}$ & 10.10 & 8.12 & 22.70 & 27.10 & 50.25 & 0.95 & - & 4.00 & 57.00 & 40.00 & 13.95 \\
\hline $\mathbf{S}_{\mathbf{4}}$ & 9.80 & 8.10 & 25.25 & 23.45 & 48.38 & 0.92 & - & 3.10 & 55.15 & 39.75 & 12.68 \\
\hline $\mathbf{S}_{5}$ & 8.75 & 8.00 & 26.10 & 17.28 & 43.22 & .90 & - & 2.50 & 46.75 & 38.25 & 11.90 \\
\hline \multicolumn{12}{|c|}{ Sunflower } \\
\hline $\mathbf{S}_{\mathbf{0}}$ & 13.00 & 8.27 & 17.55 & 31.49 & 79.86 & 1.10 & - & 5.50 & 82.40 & 42.10 & 16.45 \\
\hline$S_{1}$ & 12.10 & 8.23 & 19.00 & 30.86 & 70.04 & 1.10 & - & 5.30 & 73.80 & 41.90 & 16.00 \\
\hline $\mathbf{S}_{2}$ & 11.55 & 8.19 & 21.10 & 29.85 & 63.45 & 1.10 & - & 5.20 & 69.05 & 41.25 & 15.90 \\
\hline $\mathbf{S}_{\mathbf{3}}$ & 11.15 & 8.10 & 22.56 & 27.60 & 60.39 & 0.95 & - & 5.10 & 65.60 & 40.80 & 15.00 \\
\hline $\mathbf{S}_{4}$ & 10.70 & 8.09 & 24.95 & 23.75 & 57.36 & 0.94 & - & 4.70 & 61.80 & 40.50 & 14.70 \\
\hline $\mathbf{S}_{5}$ & 9.90 & 8.05 & 25.16 & 19.80 & 53.12 & 0.92 & - & 3.90 & 55.15 & 39.95 & 12.43 \\
\hline \multicolumn{12}{|c|}{ Canola } \\
\hline $\mathbf{S}_{\mathbf{0}}$ & 13.15 & 8.30 & 17.30 & 31.50 & 81.60 & 1.10 & - & 5.90 & 83.4 & 42.20 & 16.85 \\
\hline$S_{1}$ & 12.45 & 8.25 & 18.90 & 31.20 & 73.30 & 1.10 & - & 5,60 & 76.90 & 42.00 & 16.30 \\
\hline $\mathbf{S}_{2}$ & 12.15 & 8.21 & 20.15 & 30.13 & 70.12 & 1.10 & - & 5.40 & 74.15 & 41.95 & 16.00 \\
\hline $\mathbf{S}_{\mathbf{3}}$ & 11.90 & 8.15 & 22.24 & 28.32 & 67.45 & 0.99 & - & 5.30 & 71.80 & 41.90 & 15.30 \\
\hline $\mathbf{S}_{4}$ & 11.43 & 8.10 & 23.15 & 24.89 & 65.29 & 0.97 & - & 5.00 & 68.30 & 41.00 & 14.90 \\
\hline $\mathbf{S}_{5}$ & 10.90 & 8.07 & 24.56 & 19.74 & 63.75 & 0.95 & - & 4.55 & 64.23 & 40.22 & 13.80 \\
\hline
\end{tabular}

${ }^{*} \mathrm{~S}_{0}$ to $\mathrm{S}_{5}$ repesent soaking seeds in soutions of $0,1.0,1.5,2.0,2.5$ and $3.0 \mathrm{mM}$ salicylic acid

$* *$ Saturated water extract

Ilyas et al. (1997) who reported that cultivation of plants in sodic soils can decrease soil sodicity. Oster et al. (1996) and Badia (2000) concluded that beneficial effects of plant roots during soil amelioration include: 1-physical action of plant roots that improve soil structure and provide channels for infiltrating,2-increase in soil organic matter from plant root biomass, and 3-increased dissolution of soil $\mathrm{CaCO}_{3}$ by $\mathrm{CO}_{2}$ evolved from root respiration and decomposition of organic matter.

\section{REFERENCES}

Ahmed, S., M. Anwar and H. Ullah (1998). Wheat seed pre-soaking for improved germination. J. Agron. Crop Sci., 181 : 125127.

Amer, M.H., S. El-Guindy and W. Rafla (1989). Economic justification of drainage projects in Egypt. In: Amer, MH, Ridder, NA, (Eds.), Land drainage in Egypt. Drainage Res. Inst., Cairo, Egypt. 
Asadi, M., M.A. Heidari, M. Kazemi and A.R. Filinejad (2013). Salicylic acid induced changes in some physiological parameters in chickpea (Cicer arietinum L.) under salt stress. J. Agric. Tech., 9 (2): 311-316.

Ashraf, M. and M. Tnfail (1995). Variation in salinity tolerance in sunflower (Helianthus annus). J. Agron. Crop Sci., 174: 351-362.

Badia, D. (2000). Straw management effects on organic matter mineralization and salinity in semiarid agricultural soils. Arid Soil Res. and Rehabil., 14 : 193-203.

Bewley, J.D. (1997). Seed germination and dormancy. Plant Cell., 9: 1055-1066.

Black, C.R., D.D. Evans, J.I. White, L.E. Ensminger and F.E. Clark (1965). Methods at Soil Analysis. Ame. Soc. Agron. Inc. Madison, WI, USA

Bouwer, H. (2002). Integrated water management for the $21^{\text {st }}$ century :problems and solutions. J. Irrig. Drain. Eng., 28:193 -202.

Cayuela, E., F. Parez-Alloced and M. Caro (1996). Priming of seeds with $\mathrm{NaCl}$ induces physiological changes in tomato plants grown and salt stress. Physiol. Pl., 96: 231236.

Chapman, H.D. and P.F. Pratt (1961). Methods of Analysis for Soils, Plants and Waters. Division of Agric. Sci., California Univ., Riverside, USA.

Curtis, P.S. and A. Lauchli (1985). Response of kenaf to salt stress: Germination and vegetative growth: Crop Sci., 25: 944-949.

El-Howeity, M.A. and M.M. Asfour (2012). Response of some varieties of canola plant (Brassica napus L.) cultivated in a newly reclaimed desert to plant growth promoting rhizobacteria and mineral nitrogen fertilizer. Ann. Agric. Sci., 57 (2): 129-136.

Elkins, C.B. (1985): Plant roots as tillage tools. In: Tillage machinery systems as related to cropping systems. Proc Int. Conf. Soil Dynamics, Auburn, Alabama, USA., 3 : 1718.

El-Lakany, M.H., M.N. Hassan, A.M. Ahmed and M. Mounir (1986). Salt affected soils and marshes in Egypt; their possible use for forages and fuel production. Reclam. Reveget. Res., 5: 49-58.

El-Tayeb, M.A. (2005): Response of barley grains to the interactive of salinity and salicylic acid. Pl. Growth Regul., 45 (3): 215-224.

Francois, L.E., J.J. Donovan and E.V. Naase (1984). Salinity effects in seed yield growth and germination of grain sorghum. Agron. J. 76: 741-744.

Francois, L.E., T.J. Donovan and E.V. Maas (1992). Yield, vegetative growth and fiber length of kenaf grown on saline soil. Agron. J., $84: 592-598$.

Ghassemi, F., A.J. Jakeman and H.A. Nix (1995). Salinization of land and water resources: Human causes, extent, management and case studies. CABI Pub., Wallingford, UK.

Gray, D. (1989). Improving the quality of horticultural seed. Prof. Hort., 3:117-123.

Haigh, M.H., R.W. Barlow and L.F. Milthorpe (1986). Field emergence of tomato, carrot, and onion seed primed in an aerated salt solutions. J. Ame. Soc. Hort. Sci., 111 : 660665.

Hamada, A.M. and A.M.A. Al-Hakimi (2001). Salicylic acid versus salinity-drought induced stress on wheat seedlings. Rostl. Vyr., 47: 444 - 450.

Hanan, E.D. (2007). Influence of salicylic acid on stress tolerance during germination of T.aestivum and $H$. vulgare. Advan. Biol. Res., 1 (1-2): 40-48.

Hussain, K., K. Nawaz, A. Majeed, A. Khan, F. Lin, A. Ghani, G. Raza, S. Afghan, S. Zia-ulHussnain and K. Ali (2010). Alleviation of salinity effects by exogenous applications of salicylic acid in pearl millet (Pennisetum glaucum (L.) R. Br.) seedlings. Afr. J. Biotech., 9: 8602-8607.

IART (1997). Status in nationally coordinated research projects implementation. Institute of Agricultural Research and Training (IART) National Agric. Res. Project (NARP), Egypt, $39-40$ 
Ilyas, M., R.H. Qureshi and M. Qadir (1997). Chemical changes in saline-sodic soil after gypsum application and cropping. Soil Sci. Soc. Am. J., 57: 1580-1585.

Iwasaki, K. (1987). The effectiveness of saltaccumulating plants in reclaiming salinized soils. Japan. J. Trop. Agr., 31: 255-271.

Janda, T., G. Szalai and I. Tari (2000). Hydroponic treatment with salicylic acid decreases the effects of chilling injury in maize (Zea mays) plants. Planta, 208 : 175180.

Kandil, A.A., A.E. Sharief, W.A.E. Abido and M.M.O. Ibrahim (2012). Response of some canola cultivars (Brassica napus L.) to salinity stress and its effect on germination and seedling properties. J. Crop Sci., 3 (3): 95-103.

Kang, H.M. and M.E. Saltveit (2002): Chilling tolerance of maize, cucumber and rice seedling leaves and roots are differentially affected by salicylic acid. Plant Physiol., 115: 571-576.

Korkmaz, A. (2005). Inclusion of acetyl salicylic acid and methyl jasmonate into the priming solution improves low temperature germination and emergence of sweet pepper. Hort. Sci., 40: 197-200.

Mauromical, G. and V. Cavallaro (1995). Effects of seeds osmo-priming on germination of tomato at afferent water potentials. Seed Sci. and Technol., 23 : 393407

Mikolajczyk, M., O.S. Awotunde, G. Muszynska, D.F. Klessig and G. Dobrowolska (2000). Osmotic stress induces rapid activation of a salicylic acid-induced protein kinase and a homolog of protein kinase ASK1 in tobacco cell. Pl. Cell., 12:165-178.

Minhas, P.S. (1996). Saline water management for irrigation in India. Agric Water Manag., $30: 1-24$.

Muhammad, I. and A. Muhammad (2006). Wheat seed priming relation to salt tolerance: growth ,yield levels of free salicylic acid and polyamines. Ann. Bot. Fennici., 43:250 259.
Oster, J.D., S.R. Kaffka, M.C. Shannon and S.R Grattan (1999). Saline-sodic drainage water: A resource for forage production? In Proc $.7^{\text {th }}$ Int. Cong. on Irrig. Drain., 67-79.

Oster, J.D., I. Shainberg and I.P. Abrol (1996). Reclamation of salt affected soils. In: Agassi M. editor. Soil erosion, conservation and rehabilitation. Marcel Dekker, NY USA.

Qadir, M. and J.D. Oster (2002). Vegetative bioremediation of calcareous sodic soils: History, mechanisms and evaluation. Irrigation Sci., 21: 91-101.

Qadir, M. and J.D. Oster (2004). Crop and irrigation management strategies for saline sodic soils and waters aimed at environmentally sustainable agriculture. Sci. Total Environ., 323: 1-19.

Qadir, M., R.H. Qureshi and N. Ahmad (1996). Reclamation of saline-sodic soil by gypsum and Leptochloa fusca. Geoderma, 74 : 207217.

Richards, L.A. (1954). Diagnosis and Improvement of Saline and Alkali Soils. United States Agric. Dept., (USDA), Handbook, 60.

Robbins, C.W. (1986). Sodic calcareous soil reclamation as affected by different amendments and crops. Agron. J., 78: 916-920.

Sakhabutdinova, A.R., D.R. Fathutdinova and M.V. Bezriykova (2003). Salicylic acid prevents the damaging action of stress factors on wheat plants. Bulg. J. Plant Physiol., Special Issue, 314-319.

Senaratna, T., D. Touchell and E. Bumm. (2000). Acetyl salicylic (aspirin) and salicylic acid induce multiple stress tolerance in tomato plants. Plant Growth Regulation, 30: 157-161.

Shakirova, F.M., A.R. Sakhabutdinova and M.V. Bezrukova (2003). Changes in the hormonal status of wheat seedlings induced by salicylic acid and salinity. Plant Sci., 164: 317-322.

Singh, B. and K. Usha (2003). Salicylic acid induced physiological and biochemical changes in wheat seedlings under water stress. Plant Growth Regul., 39: 137-141. 
Tari, I., J. Csiszár, G. Szalai, F. Horváth, A. Pécsváradi, G. Kiss, Á. Szepesi, M. Szabó and L. Erdei (2002). Acclimation of tomato plants to salinity stress after a salicylic acid pre-treatment. Acta. Biol. Szegediensis, 46: $55-56$.

Tari, I., L.M. Simon, K.A. Deér, J. Csiszár, S.Z. Bajkán, G.Y. Kis and Á. Szepesi (2004). Influence of salicylic acid on salt stress acclimation of tomato plants: oxidative stress responses and osmotic adaptation. Acta Physiol. Plant, 26S: 237-243

Tisdall, J.M. and J.M. Oades (1979): Stabilization of soil aggregates by the root systems ryegrass. Aust. J. Soil Res., 17: 489-441.

Yang, N., M. Qi and C.S. Mei (2004). Endogenous salicylic acid protects rice plants from oxidative damage caused by aging as well as biotic and abiotic stress. Plant. J., 40: 909-919.

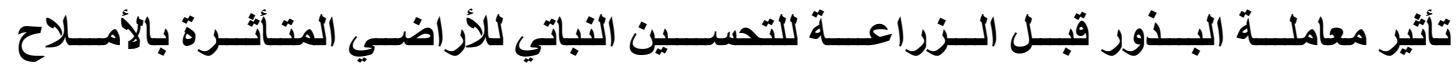

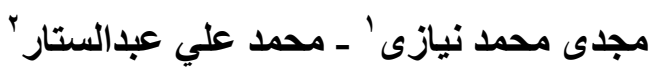

$$
\begin{aligned}
& \text { 1 - معهد بحوث الأر اضي و المياه و البيئة ـ الجيزة ـ مصرى }
\end{aligned}
$$

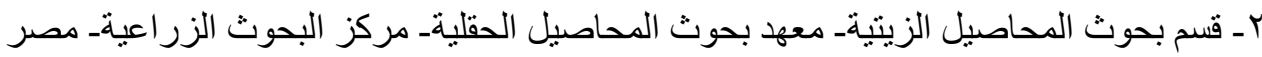

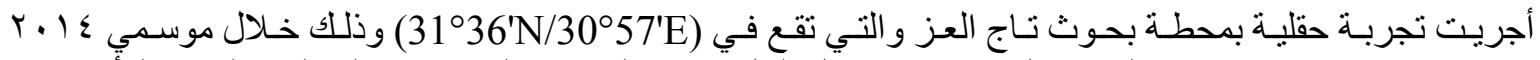

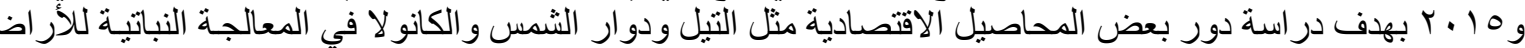

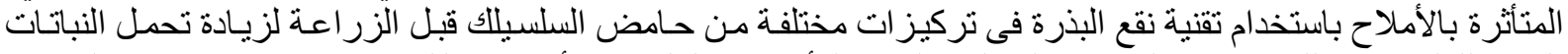

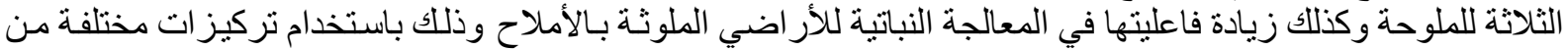

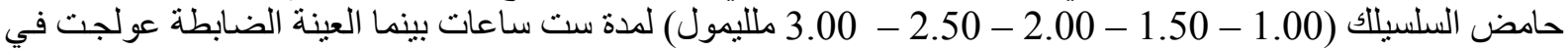

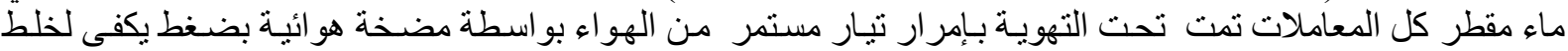

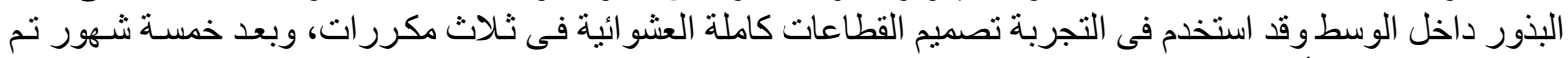

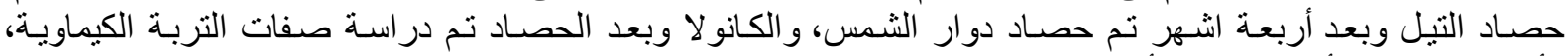

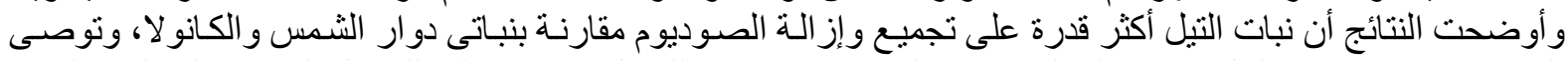

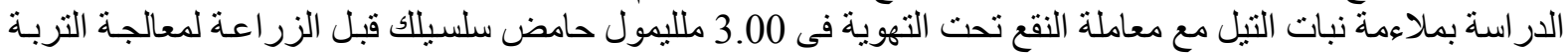

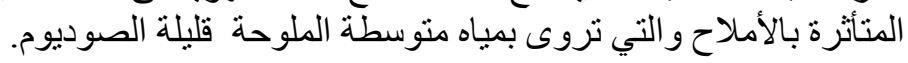

